University of Nebraska - Lincoln

DigitalCommons@University of Nebraska - Lincoln

\title{
Effect of Using Threadfin Shad as Forage for Channel Catfish Fed Daily or Every Third Day
}

\author{
Bartholomew W. Green \\ USDA ARS, bart.green@usda.gov \\ Peter Perschbacher \\ University of Arkansas at Pine Bluff \\ Gerald Ludwig \\ USDA, Agricultural Research Service
}

Follow this and additional works at: https://digitalcommons.unl.edu/usdaarsfacpub

Part of the Agriculture Commons, and the Aquaculture and Fisheries Commons

Green, Bartholomew W.; Perschbacher, Peter; and Ludwig, Gerald, "Effect of Using Threadfin Shad as Forage for Channel Catfish Fed Daily or Every Third Day" (2009). Publications from USDA-ARS / UNL Faculty. 2472.

https://digitalcommons.unl.edu/usdaarsfacpub/2472

This Article is brought to you for free and open access by the U.S. Department of Agriculture: Agricultural Research Service, Lincoln, Nebraska at DigitalCommons@University of Nebraska - Lincoln. It has been accepted for inclusion in Publications from USDA-ARS / UNL Faculty by an authorized administrator of DigitalCommons@University of Nebraska - Lincoln. 


\title{
Effect of Using Threadfin Shad as Forage for Channel Catfish Fed Daily or Every Third Day
}

\author{
BARTHOLOMEW GREEN**1 \\ U.S. Department of Agriculture, Agricultural Research Service, Aquaculture Systems Research Unit, \\ Aquaculture/Fisheries Center, University of Arkansas at Pine Bluff, Pine Bluff, Arkansas 71601, USA \\ Peter Perschbacher \\ Aquaculture/Fisheries Center, University of Arkansas at Pine Bluff, Pine Bluff, Arkansas 71601, USA

\section{GERALD LUDWIG} \\ U.S. Department of Agriculture, Agricultural Research Service, \\ Harry K. Dupree Stuttgart National Aquaculture Research Center, Stuttgart, Arkansas 72160, USA
}

\begin{abstract}
We evaluated whether stocking threadfin shad Dorosoma petenense as a forage fish in multiplebatch production ponds for channel catfish Ictalurus punctatus could substitute for formulated feed when channel catfish were fed daily or every $3 \mathrm{~d}$. A completely randomized design in a $2 \times 2$ factorial arrangement was used for the experiment, which was conducted in twelve 0.1-ha earthen ponds. Prespawn adult threadfin shad were stocked at $404 \mathrm{~kg} / \mathrm{ha}$ in six of the ponds, whereas the remaining ponds received no threadfin shad. Channel catfish stockers $(0.35 \mathrm{~kg} / \mathrm{fish})$ were stocked at $5,040 \mathrm{~kg} / \mathrm{ha}$, and fingerlings $(28.2 \mathrm{~g} / \mathrm{fish})$ were stocked at $14,820 \mathrm{fish} / \mathrm{ha}$. Channel catfish were fed a floating feed ( $32 \%$ protein) to apparent satiation daily (D; 6 ponds) or every $3 \mathrm{~d}$ (3D; 6 ponds). After $144 \mathrm{~d}$, mean channel catfish total net yield was unaffected by the presence of threadfin shad but was significantly greater for fish in the $\mathrm{D}$ treatment $(7,256 \mathrm{~kg} / \mathrm{ha})$ than for fish in the $3 \mathrm{D}$ treatment $(2,431 \mathrm{~kg} / \mathrm{ha})$. Mean fish weight at harvest also was greater in the D treatment than in the 3D treatment. The amount of feed administered in the 3D treatment was $62 \%$ of that used in the D treatment, thus reducing net total yield by $66 \%$ and slowing growth in fish from the 3D treatment. Nearly $90 \%$ of stockers in the $3 \mathrm{D}$ treatment failed to reach market size $(0.68 \mathrm{~kg} / \mathrm{fish})$ and would have required a third season to reach harvest weight. At the rate used in this experiment, stocking of threadfin shad as forage fish into channel catfish production ponds did not appear to be a viable method of substituting for formulated feed during the growing season.
\end{abstract}

Catfish farmers strive to reduce production costs in response to low catfish prices or high production input prices. Because feed represents the largest component of variable costs, improved feed management could result in lower feed expenditures. Restricting feed ration is one management strategy that is contemplated to reduce production costs. Net production and total amount of feed given to channel catfish Ictalurus punctatus did not decrease significantly when fish were fed for only $6 \mathrm{~d}$ /week compared with $7 \mathrm{~d} /$ week (Li et al. 2005). Results of other feed restriction strategies have been mixed and appear to depend on the duration of feed restriction. Channel catfish that were not fed for 3 weeks during an 18-week experiment regained lost

\footnotetext{
* Corresponding author: bart.green@ars.usda.gov

${ }^{1}$ Present address: U.S. Department of Agriculture, Agricultural Research Service, Harry K. Dupree Stuttgart National Aquaculture Research Center, P.O. Box 1050, 2955 Highway 130 E, Stuttgart, Arkansas 72160, USA.
}

Received November 28, 2007; accepted March 5, 2008 Published online February 5, 2009 weight once feeding was resumed, and size at harvest did not differ significantly between feed-restricted and control fish (Kim and Lovell 1995). Restricting feed for longer periods has generally resulted in lower channel catfish production and lower feed usage (Kim and Lovell 1995; Li et al. 2004, 2005; Reigh et al. 2006). However, stocking of forage fish may substitute for formulated ration during periods of restricted feeding.

Stocking of forage fish often is recommended for channel catfish broodfish nutrition during winter months (Kelly 2004). Channel catfish broodfish grew more over the winter and had a higher gonadosomatic index in ponds where blue tilapia Oreochromis aureus were stocked as forage fish (Torrans and Lowell 2001). When blue tilapia were stocked as forage fish in production ponds, channel catfish yield did not differ significantly from that in control ponds, but significantly more feed was used because the blue tilapia also consumed formulated feed (Torrans and Lowell 1987). Stocking of a forage fish species that competes for feed with the culture species is counterproductive. An ideal forage fish for use with channel catfish would have a 
small size at sexual maturity and high fecundity and would not readily consume formulated feed. Threadfin shad Dorosoma petenense have all three of these characteristics, and there are anecdotal reports of this species being used as a forage fish in channel catfish broodfish ponds. There is little other published information on the use of forage fish in channel catfish production ponds.

The objective of this study was to determine whether threadfin shad that were stocked as forage fish could supplement formulated feed when channel catfish in multiple-batch production were fed daily (D treatment) or every $3 \mathrm{~d}$ (3D treatment).

\section{Methods}

Twelve 0.1-ha earthen ponds located at the Aquaculture Research Station (University of Arkansas, Pine Bluff) were used for this study, which had a completely randomized design in a $2 \times 2$ factorial arrangement. Factors tested were feeding frequency (D or 3D) and threadfin shad presence (S) or absence (NS).

Agricultural limestone (250 mesh; $1,120 \mathrm{~kg} / \mathrm{ha}$ ) was applied to all ponds before inundation. Once all ponds were filled with well water in mid-March 2003, a fertilization program adapted from Ludwig et al. (1998) was initiated. Cottonseed meal $(280 \mathrm{~kg} / \mathrm{ha}$ on 18 March; $112 \mathrm{~kg} / \mathrm{ha}$ on 25 March; $28 \mathrm{~kg} / \mathrm{ha}$ on 8 and 22 April; and $56 \mathrm{~kg} / \mathrm{ha}$ on 29 April and 8 May) and 19-1919 granular fertilizer (26 kg/ha on 18 March; $13 \mathrm{~kg} / \mathrm{ha}$ on $25 \mathrm{March} ; 6.5 \mathrm{~kg} / \mathrm{ha}$ on 8 and $22 \mathrm{April} ; 13 \mathrm{~kg} / \mathrm{ha}$ on 29 April; and $6.5 \mathrm{~kg} / \mathrm{ha}$ on 8 May) were added to each pond. The granular fertilizer was dissolved in pond water before application.

Prespawn adult threadfin shad were stocked incrementally into S-treatment ponds at $449 \pm 43 \mathrm{~kg} / \mathrm{ha}$ (mean \pm SD) from 22 April to 15 May 2003. Poststocking mortality of threadfin shad was observed in all ponds, especially after the initial stocking on 2224 April. The initial stocking accounted for $56-70 \%$ of the total biomass of threadfin shad stocked. Low threadfin shad mortality was observed after the other stocking events because of improved transport and handling. Salt $(\sim 0.5 \%$; Jensen 1990$)$ and quinaldine sulfate $(\sim 6 \mathrm{mg} / \mathrm{L}$; A. Goodwin, University of Arkansas, Pine Bluff, personal communication) were added to hauling tank water. Total recorded poststocking mortality of threadfin shad was $45 \pm 29 \mathrm{~kg} / \mathrm{ha}$. Thus, the estimated initial stocked biomass of threadfin shad was $404 \pm 20 \mathrm{~kg} / \mathrm{ha}$. At stocking, threadfin shad averaged $5.0 \mathrm{~g}$ in weight and $7.8 \mathrm{~cm}$ total length (TL).

Stocker channel catfish (mean weight $=0.35 \mathrm{~kg} / \mathrm{fish}$ ) were stocked into ponds at $5,040 \mathrm{~kg} / \mathrm{ha}$ on 29-30 May. On 6 June, ponds were stocked with fingerling channel catfish (mean weight $=28.2 \mathrm{~g} / \mathrm{fish}$ ) at $14,820 \mathrm{fish} / \mathrm{ha}$.
Beginning 31 May, channel catfish were offered floating, extruded feed ( $32 \%$ protein) either daily or every third day. Fish were fed to apparent satiation over a 20-min period. Because of disease outbreaks or sampling and harvesting activities, $20 \mathrm{~d}$ of feeding were missed in D treatment ponds and $5 \mathrm{~d}$ of feeding were missed in 3D treatment ponds. On 16 June, an outbreak of enteric septicemia of catfish was detected in all ponds; fish were therefore taken off feed from 16 to 23 June. A random sample of fish from each pond was captured by seine net on 15 July, 12 August, and 10 September, and 100 fish/pond were weighed individually to the nearest $0.05 \mathrm{~kg}$ to monitor growth. All fish were returned alive to their respective ponds.

Daily fish biomass was estimated by interpolation for each pond based upon stocking, sampling, harvest, and recorded mortality data. The daily feed rate expressed as a percentage of biomass was calculated for each pond as the daily feed ration divided by the estimated fish biomass on that day. The occurrence of compensatory growth was evaluated by dividing total net yield by the number of days of feeding ( $\mathrm{Li}$ et al. 2005).

Pond dissolved oxygen (DO) concentration and temperature were monitored daily by a polarographic oxygen sensor equipped with a thermistor. An electric paddlewheel aerator $(0.373 \mathrm{~kW})$ was activated when pond DO concentration fell below $3.5 \mathrm{mg} / \mathrm{L}$.

At harvest, which occurred from 20 to 23 October, each pond was seined twice to capture the greatest percentage of fish possible. A seine with the smallest mesh size available to us $(1.27-\mathrm{cm}$ square mesh) was used initially. However, hundreds of threadfin shad became caught by their gills in the seine net during each of the first two seine hauls attempted. The time required to manually remove the gilled threadfin shad from the seine jeopardized the survival of landed channel catfish. Manual removal of gilled threadfin shad often resulted in physical mutilation of the fish, which limited the data that could be collected. Thus, we decided to complete the harvest using a seine with 2.54-cm square mesh, through which threadfin shad passed. However, use of the larger mesh meant that only a portion of the threadfin shad population in the pond could be recovered. Each pond was drained after seining. The total weight of threadfin shad recovered from each treatment pond was recorded. The relative abundance of threadfin shad trapped in the mud was estimated after draining each treatment pond, but no attempt was made to recover mud-bound threadfin shad. In each pond, channel catfish fingerlings and stockers were separated and then were counted and weighed en masse. Samples of 100 fingerlings and stockers from each pond were weighed individually. 
TABLE 1.-Mean gross yield ( $\mathrm{kg} / \mathrm{ha})$, net yield ( $\mathrm{kg} / \mathrm{ha})$, individual weight $(\mathrm{kg})$ at harvest, overall survival $(\%)$, and net feed conversion ratio (FCR) for channel catfish stockers and fingerlings that were reared for 144 d (May-October 2003) in multiplebatch production ponds at the Aquaculture Research Station (University of Arkansas, Pine Bluff); channel catfish were given a floating feed (32\% protein) daily (D) or every $3 \mathrm{~d}(3 \mathrm{D})$, and ponds either were stocked with threadfin shad as forage fish (S) or were not stocked with threadfin shad (NS). The significance of between-treatment comparisons for each performance variable is given at bottom (ns $=$ not significant, $P>0.05 ; * P<0.05 ; * * P<0.01$ ).

\begin{tabular}{|c|c|c|c|c|c|c|c|c|}
\hline \multirow[b]{2}{*}{ Treatment } & \multicolumn{2}{|c|}{ Stocker } & \multicolumn{2}{|c|}{ Fingerling } & \multicolumn{2}{|c|}{ Individual weight $(\mathrm{kg})$} & \multirow[b]{2}{*}{ Survival (\%) } & \multirow[b]{2}{*}{ Net FCR } \\
\hline & Gross yield & Net yield & Gross yield & Net yield & Stocker & Fingerling & & \\
\hline S-D & 11,312 & 6,273 & 1,170 & 1,070 & 0.82 & 0.11 & 83.6 & 1.62 \\
\hline NS-D & 10,977 & 5,922 & 1,353 & 1,247 & 0.81 & 0.14 & 86.8 & 1.74 \\
\hline S-3D & 7,050 & 2,003 & 534 & 435 & 0.47 & 0.04 & 88.6 & 1.84 \\
\hline NS-3D & 6,978 & 1,957 & 579 & 466 & 0.46 & 0.05 & 88.0 & 1.96 \\
\hline$D$ versus 3D & $* *$ & $* *$ & $* *$ & $* *$ & $* *$ & $* *$ & ns & ns \\
\hline S versus NS & $\mathrm{ns}$ & $\mathrm{ns}$ & ns & $\mathrm{ns}$ & $\mathrm{ns}$ & * & $\mathrm{ns}$ & ns \\
\hline Interaction & $\mathrm{ns}$ & ns & ns & ns & ns & ns & ns & ns \\
\hline
\end{tabular}

Net feed conversion ratio (FCR) was calculated for each pond as the total quantity of administered feed divided by the sum of the net total channel catfish yield and the dead fish recovered.

During harvest, captured fish (including some threadfin shad that had been entrained with the channel catfish) were held in sock nets $(6.35-12.7-\mathrm{cm}$ mesh) before collection of weight data. We observed that some channel catfish in the holding socks from S-3D ponds had grossly distended abdomens. Twelve adult channel catfish were collected from two of the S-3D ponds and were euthanized; their stomachs were dissected, and stomach contents were examined. At the time of collection, these fish had not been fed for 5$6 \mathrm{~d}$.

Data sets were imported into the Statistical Analysis System version 9.1.3 (SAS Institute, Inc., Cary, North Carolina), where the general linear models (Littell et al. 2002) and mixed models procedures (Littell et al. 1996) were used for data analysis. Differences were considered significant at the 0.05 level.

\section{Results}

Channel catfish gross and net yields were unaffected by the presence of threadfin shad but were significantly greater in the $\mathrm{D}$ ponds than in the 3D ponds (Table 1). No significant treatment interaction was detected for gross or net yield. Mean channel catfish total gross yields (stocker gross yield + fingerling gross yield) after $144 \mathrm{~d}$ were $12,482 \mathrm{~kg} / \mathrm{ha}$ for the S-D treatment, $12,330 \mathrm{~kg} / \mathrm{ha}$ for the NS-D treatment, $7,584 \mathrm{~kg} / \mathrm{ha}$ for the S-3D treatment, and $7,557 \mathrm{~kg} / \mathrm{ha}$ for the NS-3D treatment. Net yield of stocker channel catfish was $208 \%$ greater in the D treatment than in the 3D treatment; net yield of fingerling channel catfish was $157 \%$ greater in the $\mathrm{D}$ treatment than in the 3D treatment. Threadfin shad recovery at harvest was 25.7 $\mathrm{kg} / \mathrm{ha}$ from the $\mathrm{S}-\mathrm{D}$ ponds and $21.8 \mathrm{~kg} / \mathrm{ha}$ from the $\mathrm{S}-$
3D ponds. However, we estimated the relative abundance of threadfin shad (size range $\approx 2.5-15.0$ $\mathrm{cm}$ TL) observed trapped in the mud to be common in all $\mathrm{S}$ ponds after draining, and an unknown number were trapped in the mud but were not visible. Thus, it was impossible to quantify the total threadfin shad biomass at harvest.

At harvest, mean stocker weights were $0.82 \mathrm{~kg} / \mathrm{fish}$ for the S-D treatment and $0.81 \mathrm{~kg} /$ fish for the NS-D treatment, and these were significantly greater than the weights of $0.47 \mathrm{~kg} /$ fish for the S-3D treatment and $0.46 \mathrm{~kg} / \mathrm{fish}$ for the NS-3D treatment (Table 1). Mean fingerling weight in the $S$ treatment $(0.10 \mathrm{~kg})$ was significantly greater than that in the NS treatment $(0.08$ $\mathrm{kg}$; Table 1). Mean fingerling weight also differed significantly between the $\mathrm{D}(0.13 \mathrm{~kg} / \mathrm{fish})$ and $3 \mathrm{D}(0.05$ $\mathrm{kg} /$ fish) treatments (Table 1).The percentage of marketable fish (those exceeding $0.68 \mathrm{~kg}$ ) among harvested stockers was $76.6 \%$ for the S-D treatment and $78.3 \%$ for the NS-D treatment; these values were significantly greater than the $12.8 \%$ observed for the S-3D treatment and the $11.2 \%$ observed for the NS-3D treatment. Individual stocker size at harvest was unaffected by threadfin shad presence.

Feed was offered on $119 \mathrm{~d}$ in the D treatment and 43 $\mathrm{d}$ in the $3 \mathrm{D}$ treatment. Fish in the $\mathrm{D}$ treatment consumed significantly more feed (mean $=12,453$ $\mathrm{kg} / \mathrm{ha}$ ) than did fish in the 3D treatment (mean $=4,704$ $\mathrm{kg} / \mathrm{ha}$ ). However, fish in the 3D treatment consumed significantly more feed at each meal as a percentage of fish biomass than did fish in the D treatment (Figure 1). Feed consumption was unaffected by threadfin shad presence. Weekly mean feed consumption (\% of fish biomass/d) averaged $1.21 \%$ for the S-D treatment, $1.27 \%$ for the NS-D treatment, $1.75 \%$ for the S-3D treatment, and $1.76 \%$ for the NS-3D treatment. Based on the examination of total net yield per day of feeding, compensatory growth did not occur in the 3D feed 


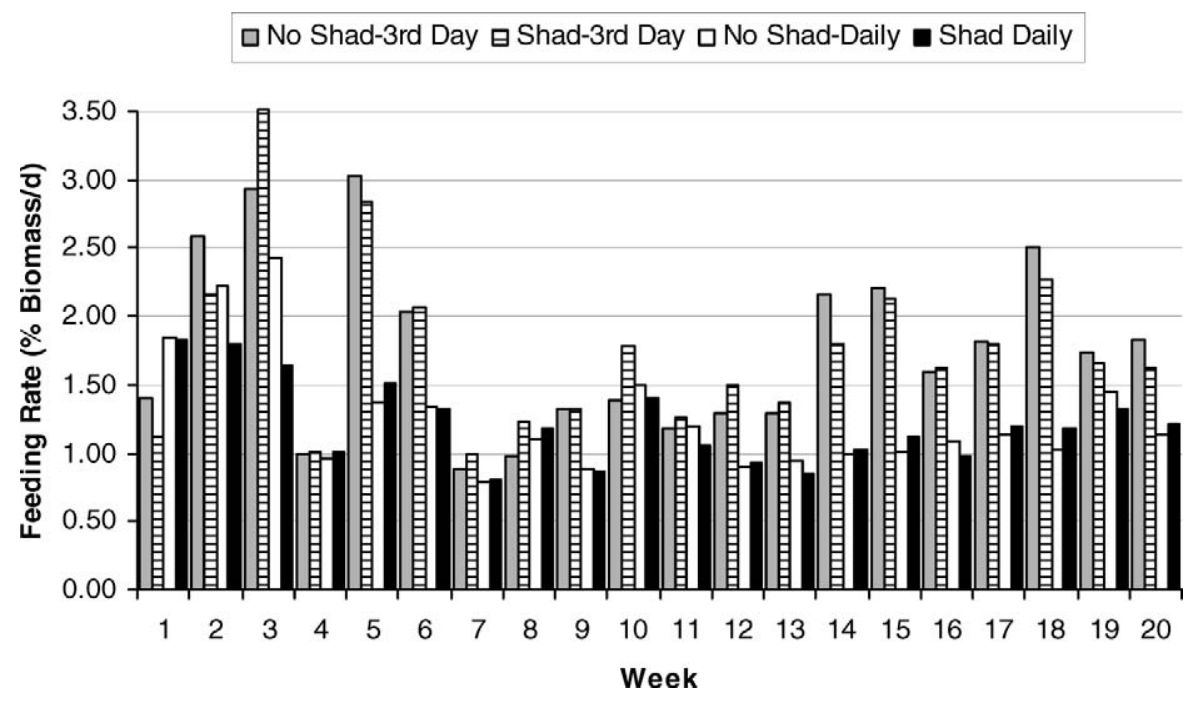

FIGURE 1.-Mean daily feed consumption (\% of fish biomass per day of feeding) by in multiple-batch-cultured channel catfish fed daily or every $3 \mathrm{~d}$ (May-October 2003) at the Aquaculture Research Station (University of Arkansas, Pine Bluff); ponds either were or were not stocked with threadfin shad as forage fish.

treatment and was not affected by the presence of threadfin shad. The mean total net yield per day of feeding was $61.7 \mathrm{~kg} \cdot \mathrm{ha}^{-1} \cdot \mathrm{d}^{-1}$ for the S-D treatment, $60.2 \mathrm{~kg} \cdot \mathrm{ha}^{-1} \cdot \mathrm{d}^{-1}$ for the NS-D treatment, 56.7 $\mathrm{kg} \cdot \mathrm{ha}^{-1} \cdot \mathrm{d}^{-1}$ for the S-3D treatment, and 56.4 $\mathrm{kg} \cdot \mathrm{ha}^{-1} \cdot \mathrm{d}^{-1}$ for the NS-3D treatment. Net FCR was unaffected by feeding frequency or threadfin shad presence (Table 1).

Observations made during periodic growth samples of channel catfish yielded no external evidence (e.g., visibly distended abdomens) that fish in the $\mathrm{S}-3 \mathrm{D}$ treatment had consumed threadfin shad. However, some channel catfish did consume threadfin shad; 4 of the 12 stomachs examined at harvest contained only threadfin shad. These individuals weighed from 0.4 to $0.8 \mathrm{~kg} /$ fish and had consumed 3-13 threadfin shad each (5-11\% of channel catfish body weight). All other stomachs were empty.

\section{Discussion}

The 3D treatment used $62 \%$ less feed than the $\mathrm{D}$ treatment but reduced net total yield by $66 \%$ and slowed fish growth relative to that observed in the D treatment. Consequently, $88 \%$ of stocker channel catfish were smaller than the $0.68-\mathrm{kg}$ market size and required a third growing season to reach market weight.

Threadfin shad, at the stocking rate used, failed to provide a substitute for formulated feed. It is likely that channel catfish in $\mathrm{D}$ and $3 \mathrm{D}$ ponds consumed some threadfin shad, but we are unable to quantify this consumption because the total threadfin shad biomass at harvest and the extent of threadfin shad reproduction are unknown. However, the absence of differences between $\mathrm{D}$ and 3D feed treatments in individual weight at harvest indicates that any threadfin shad consumption did not affect channel catfish growth. Threadfin shad did spawn in treatment ponds, as indicated by the presence of age-0 fish along pond margins throughout the summer. Small schools of age-0 threadfin shad were often observed feeding on the few stray feed pellets entrapped in marginal vegetation.

Threadfin shad spawn repeatedly over the course of the summer. Yearling threadfin shad that are stocked into lakes and reservoirs apparently spawn multiple times beginning in May, based on the continual capture of age-0 fish during June-September (Heidinger and Imboden 1974; DeVries et al. 1991). In addition, age-0 threadfin shad can mature and spawn successfully in one season (Heidinger and Imboden 1974; Kuklinski 2007). Threadfin shad population size increased from 1,750 fish/ha to 21,475-32,400 fish/ha during AprilNovember and yield averaged $1,375 \mathrm{~kg} / \mathrm{ha}$ when this species was co-stocked in ponds with channel catfish (Lo Giudice et al. 2004). Thus, it is reasonable to expect that the estimated initial biomass of stocked threadfin shad adults (404 kg/ha; $>80,000 \mathrm{fish} / \mathrm{ha})$ in this experiment would result in a substantial biomass of age-0 fish.

In this study, the presence or absence of threadfin shad did not affect channel catfish yield. Lo Giudice et al. (2004) similarly reported that channel catfish yield 
and growth were unaffected by the presence or absence of threadfin shad. In that experiment, 9.0-g channel catfish fingerlings were stocked in 10 ponds at 13,200 fish/ha; five replicate ponds were stocked with adult threadfin shad at $16.5 \mathrm{~kg} / \mathrm{ha}$. After $208 \mathrm{~d}$, mean channel catfish yield, individual weight, and FCR did not differ between ponds containing threadfin shad and those that lacked threadfin shad. The similar FCR indicated that threadfin shad probably were not a component of the channel catfish diet during the growing season. Use of blue tilapia as forage fish also did not significantly affect channel catfish net yield or FCR relative to ponds that did not contain blue tilapia (Torrans and Lowell 1987). Channel catfish are apparently unable to effectively prey on age- 0 forage fish until water temperature declines in October, making forage fish more vulnerable to predation (Torrans and Lowell 1987, 2001). Stomach content analysis demonstrated that $21-\mathrm{cm}$ TL and larger channel catfish can consume age-0 forage fish when cool water temperatures facilitate the capture of these prey (Perschbacher 2001).

While they were held in net socks at harvest, some channel catfish in this experiment encountered and consumed threadfin shad at a rate equivalent to $5-11 \%$ of body weight. Given the $4,188-\mathrm{kg} / \mathrm{ha}$ difference in stocker net yield between the $\mathrm{D}$ and $3 \mathrm{D}$ treatments, a large biomass of threadfin shad probably would be required to sustain growth of channel catfish fed every 3 $\mathrm{d}$ at a level similar to the growth achieved with daily feeding. Production of a high standing stock of threadfin shad would require stocking of a large number of broodfish and probably more than one growing season. Because the lower lethal temperature for threadfin shad is around $5-7^{\circ} \mathrm{C}$ (Parsons and Kimsey 1954), it is questionable whether threadfin shad would survive through the winter in the southern United States in levee-type channel catfish ponds, which are 1-2 m deep on average. Threadfin shad are known to survive through most winters in channel catfish ponds in western Alabama, but those watershed ponds are deeper (depth $=3.0-3.6 \mathrm{~m})$ than levee-type ponds.

Feed deprivation generally elicits hyperphagia in fish once the full feed ration is restored. Hyperphagia often is associated with compensatory growth, or increased weight gain, and improved FCR. In this experiment, daily feed consumption as a percentage of channel catfish biomass was $0.49-0.54 \%$ greater in the $3 \mathrm{D}$ treatment than in the $\mathrm{D}$ treatment. However, there was no indication of hyperphagia and compensatory growth (based on examination of net production per day of feeding) or an improvement in FCR in the 3D treatment, probably because the re-feeding period lasted only $1 \mathrm{~d}$. In other pond studies, channel catfish subjected to varying degrees of feed deprivation generally exhibited hyperphagia and compensatory growth, but FCR improvements were usually not statistically significant and individual channel catfish weight at harvest was lower than that of fish fed daily to satiation (Kim and Lovell 1995; Li et al. 2004, 2005; Reigh et al. 2006).

Weight lost by individual channel catfish during short-term feed restriction may be recovered within one growing season (Kim and Lovell 1995; Li et al. 2005). Longer-term weight loss, however, is unrecoverable during one growing season. In this experiment, feeding channel catfish for 76 fewer days (3D treatment) reduced net production by $54 \mathrm{~kg} \cdot \mathrm{ha}^{-1} \cdot$ lost feed $\mathrm{d}^{-1}$ relative to the $\mathrm{D}$ treatment. Relative to channel catfish that were fed daily, net production of fish fed every other day (55 fewer feed days) was reduced by 26 $\mathrm{kg} \cdot \mathrm{ha}^{-1} \cdot$ lost feed $\mathrm{d}^{-1}$ for fish given a feed containing $28 \%$ protein and by $23 \mathrm{~kg} \cdot \mathrm{ha}^{-1} \cdot$ lost feed $\mathrm{d}^{-1}$ for fish given a feed containing $32 \%$ protein ( $\mathrm{Li}$ et al. 2004). In evaluating the effects of periodic feed deprivation, $\mathrm{Li}$ et al. (2005) reported that channel catfish net production in ponds was reduced by $14-39 \mathrm{~kg} \cdot \mathrm{ha}^{-1} \cdot$ lost feed $\mathrm{d}^{-1}$ when fish were fed for 21-64 fewer days relative to fish that were fed daily. In another pond study, channel catfish net production relative to that of daily fed fish declined by $18 \mathrm{~kg} \cdot \mathrm{ha}^{-1} \cdot$ lost feed $\mathrm{d}^{-1}$ when fish were fed for 46 fewer days and by $25 \mathrm{~kg} \cdot \mathrm{ha}^{-1} \cdot$ lost feed d $^{-1}$ when fish were fed for 61 fewer days (Reigh et al. 2006). While the experimental conditions varied among these studies, the reduction in net production per lost day of feeding appears to become larger as the number of lost days during the production season increases.

At the rate used in this experiment, stocking of threadfin shad as forage fish into channel catfish production ponds does not appear to be a viable method of substituting for formulated feed when water temperatures are warm. Either channel catfish in this study did not effectively prey on threadfin shad during the growing season or the threadfin shad that were consumed did not support fast growth. Restricting feeding to every third day during the growing season in response to market or economic constraints reduces fish growth and yield and prolongs the grow-out period. Daily feeding of channel catfish was necessary to achieve maximum production and fish size in this study. However, additional research is necessary for determining the optimal feeding strategy to maximize profit under a variety of economic conditions.

\section{Acknowledgments}

The Agricultural Research Service (U.S. Department of Agriculture) and Aquaculture Research Station (University of Arkansas, Pine Bluff) support personnel 
are thanked for their assistance during this study. The authors thank Steve Lewis and colleagues at the Arkansas Game and Fish Commission for providing threadfin shad. Mention of trade names or commercial products is solely for the purpose of providing specific information and does not imply recommendation or endorsement by the U.S. Department of Agriculture.

\section{References}

DeVries, D. R., R. A. Stein, J. G. Miner, and G. G. Mittelbach. 1991. Stocking threadfin shad: consequences for young-of-year fishes. Transactions of the American Fisheries Society 120:368-381.

Heidinger, R., and F. Imboden. 1974. Reproductive potential of young-of-the-year threadfin shad (Dorosoma petenense) in southern Illinois lakes. Transactions of the Illinois State Academy of Science 67:397-401.

Jensen, G. L. 1990. Transportation of warmwater fish: procedures and loading rates. Southern Regional Aquaculture Center Publication 393, Stoneville, Mississippi.

Kelly, A. M. 2004. Broodfish management. Pages 129-144 in C. S. Tucker and J. A. Hargreaves, editors. Developments in aquaculture and fisheries science: biology and culture of channel catfish. Elsevier, Amsterdam.

Kim, M. K., and R. T. Lovell. 1995. Effect of restricted feeding regimens on compensatory weight gain and body tissue changes in channel catfish Ictalurus punctatus in ponds. Aquaculture 135:285-293.

Kuklinski, K. E. 2007. Prolonged spawning of adult threadfin shad and contribution of age- 0 threadfin shad as a brood source of summer larval presence in Hugo Reservoir, Oklahoma. Proceedings of the Annual Conference Southeastern Association of Fish and Wildlife Agencies 60(2006): 194-199.

Li, M. H., B. B. Manning, E. H. Robinson, and B. G. Bosworth. 2004. Effects of dietary protein on production characteristics of pond-raised channel catfish fed once daily or once every other day to satiation. North American Journal of Aquaculture 66:184-190.
Li, M. H., E. H. Robinson, and B. G. Bosworth. 2005. Effects of periodic feed deprivation on growth, feed efficiency, processing yield, and body composition of channel catfish Ictalurus punctatus. Journal of the World Aquaculture Society 36:444-453.

Littell, R. C., G. A. Milliken, W. W. Stroup, and R. D. Wolfinger. 1996. SAS system for mixed models. SAS Institute, Cary, North Carolina.

Littell, R. C., W. W. Stroup, and R. J. Freund. 2002. SAS for linear models, 4th edition. SAS Institute, Cary, North Carolina.

Lo Giudice, G. M., D. R. Bayne, and T. J. Popma. 2004. Threadfin shad Dorosoma petenense effects on water quality, phytoplankton, and channel catfish production in ponds. Journal of the World Aquaculture Society 35:345-356.

Ludwig, G. M., N. M. Stone, and C. Collins. 1998. Fertilization of fish fry ponds. Southern Regional Aquaculture Center Publication Number 469, Delta Research and Extension Center, Mississippi State University, Stoneville.

Parsons, J. W., and J. B. Kimsey. 1954. A report on the Mississippi threadfin shad. Progressive Fish-Culturist 16:179-181.

Perschbacher, P. W. 2001. Observations on cultured channel catfish fish foraging behavior. Journal of Applied Aquaculture 11:75-82.

Reigh, R. C., M. B. Williams, and B. J. Jacob. 2006. Influence of repetitive periods of fasting and satiation feeding on growth and production characteristics of channel catfish, Ictalurus punctatus. Aquaculture 254:506-516.

Torrans, E. L., and F. Lowell. 1987. Effects of blue tilapia/ channel catfish polyculture on production, food conversion, water quality and channel catfish off-flavor. Proceedings of the Arkansas Academy of Science 41:82-86.

Torrans, E. L., and F. Lowell. 2001. Use of tilapia as supplemental forage for channel catfish broodstock. North American Journal of Aquaculture 63:215-221. 